Department of Biology,

Animal Reproduction Research Institute.

\title{
EFFECT OF DIETARY SUPPLEMENTATION WITH CHELATED COPPER METHIONINE ON SOME CHEMICAL METABOLITES AND OVARIAN ACTIVITY OF DOE RABBIT AND THEIR LITTER PERFORMANCE
}

(With 3 Tables and 8 Figures)

By

\section{GALILA A. EL-RAFEY; UMIMA M. MANSOUR; M. HEGAZY and A.A. RAMADAN* \\ *: Department of Immunology, Animal Health Research Institute.}

(Received at 1/3/2007)

تأثير النحاس المحمل على المثيونين كأضافه للعليقه على بعض القياسات

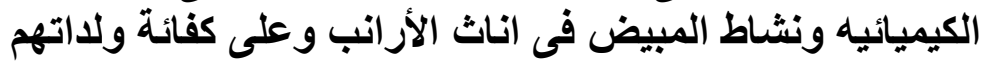

جليله عبل الباقى الرافعى ، أمبيه مبروك منصور ، محمد أحمد حجازى ، أحمد عبد الفضيل رمضان ميرو منصون

تهدف هذه الدراسه الى تحديد تأثير أضافة النحاس المحمل على المثيونين للعليقه على تركيز

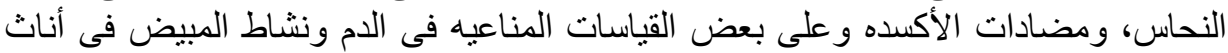

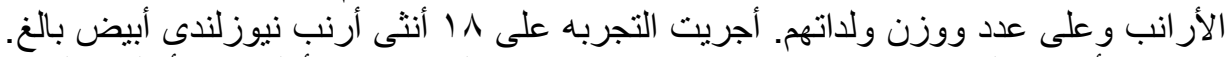

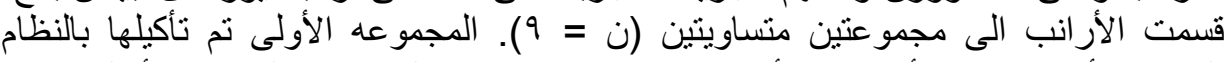

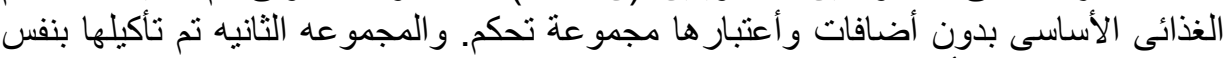

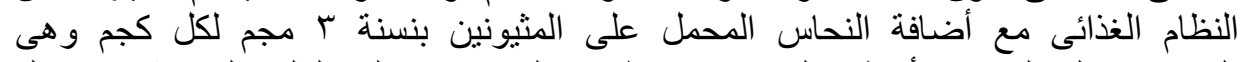

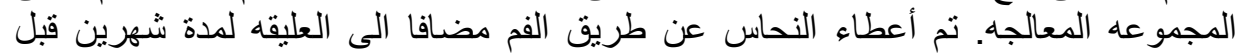

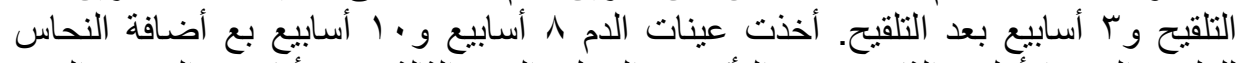

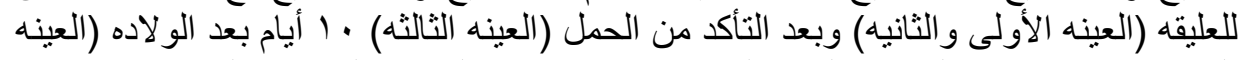

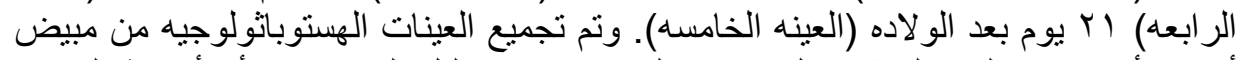

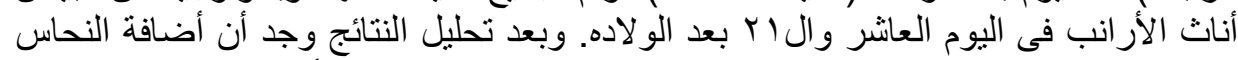

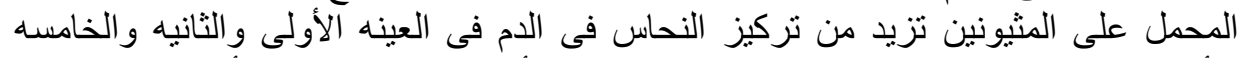

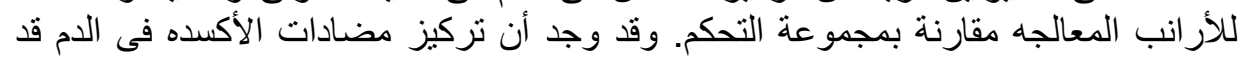

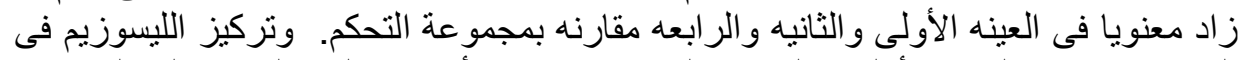

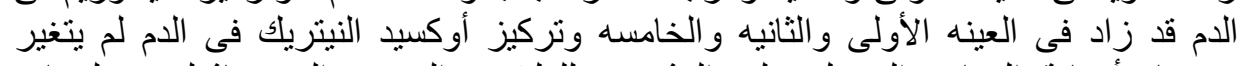

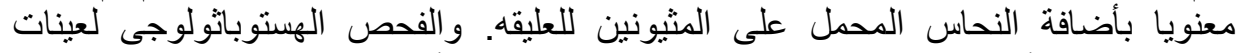

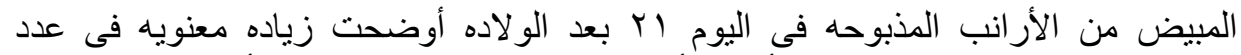

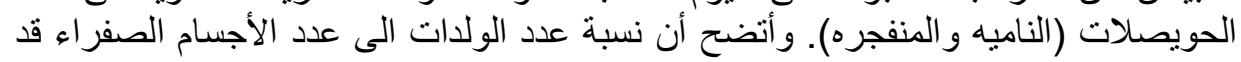




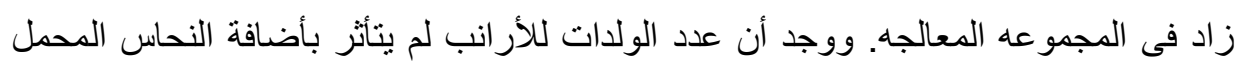

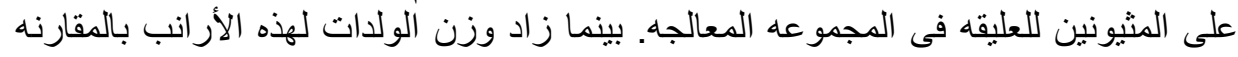

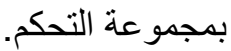

\section{SUMMARY}

The objective of this study was designed to determine the effect of dietary chelated copper methionine supplementation on the serum copper and antioxidant concentrations, some immunological parameters, ovarian activity of 18 New Zealand white mature doe rabbits and the number and weight of their litters. Animals were divided into two equal groups $(n=9)$. The first group was fed basal diet and kept as control, while the second group fed basal diet with addition of copper methionine ( $3 \mathrm{mg} / \mathrm{kg}$ ) and kept as treated group. It was given orally two months before matting and until three weeks post breeding. Blood samples were taken 8 weeks after supplementation (first sample), 10 weeks after supplementation (second sample) during pregnancy (third sample), 10 days after parturition (fourth sample); 21days after parturition (fifth sample). Histological samples of the ovaries were collected from dams 10 and 21 days after parturition Chelated copper supplementation significantly increased serum copper concentration in the first, second and fifth samples compared to control. Serum total antioxidant concentrations were significantly increased in the first, second, and fourth samples compared with their controls. The serum concentration of lysozyme were significantly increased in the first, second and fifth samples; while serum nitric oxide concentrations did not significantly change between the control and treated group. Ovarian sections of copper methionine treated does, slaughtered 21 days post parturition, revealed significant increase in the number of dominant follicles (ovulatory and non ovulatory). The percentage of births/ number of corpora lutea was increased in treated group. The number of born litters was significantly unaffected by supplementation whereas weight of litters at birth was significantly increased in the treated group. Mortality rate of the litters at 21 days postpartum was significantly lower in the treated group compared with the control one.

Key words: Rabbits, ovarian activity, copper methionine, chemical metabolites

\section{INTRODUCTION}


Copper is one of the most complex trace elements involved in animal metabolism especially in cattle and sheep. It is required in the structure and function of many enzymes and is involved in most oxidative reactions, and metabolic pathways (Thomas, 1994). Copper is required for mitochondrial function and energy transfer, for tissue and bone growth, for pigmentation of hair, and for leukocyte functions (Nicholas, 1988). Therefore, a dietary copper deficiency could easily implicate as the cause of infertility, anemia, or suppressed immune functions (Underwood and Suttle, 1999). Initial research with stressed feed calves demonstrated that dietary supplementation with copper markedly improved dry matter intake and growth rate (Nockels et al., 1993). Oikawski et al., 1990 concluded that sheep feed have compromised immune function due to lower copper and hence are at risk of increased susceptibility to infection. Measures of reproductive performance and weaning weight of the new born that will respond to appropriate copper supplementation have shown inconsistent results in ruminant studies. This include reduced days to first estrus (Campbell et al., 1999), no improvement in pregnancy rate (Muehlenbein et al., 2001), improved pregnancy rate and kilograms of calf weaned per cow (Ahola et al., 2004) and beneficial effects on first service conception rate (Vanegas et al., 2004). However, the effect of copper supplementation on ovarian activity remains need more research. Studies of the bioavailability of organic and inorganic minerals reported that calves fed $\mathrm{Cu}$ proteinate had higher $\mathrm{Cu}$ liver and serum levels than calves fed $\mathrm{Cu}$ sulfate (Kincaid et al., 1986). Kropp (1990) found that feeding chelated minerals to first-calf cows 30 days before the breeding season caused more cows to exhibit estrus and conceive after first service than did feeding inorganic minerals. Chelating copper to an amino acid before feeding were necessary for brush border uptake of copper and could increase copper availability and improve its performance (Swenson et al., 1998 and Nockels et al., 1993). The objective of this study was designed to determine the effect of dietary chelated copper methionine supplementation on the serum copper, antioxidant concentrations and the immune status of doe rabbit that reflect the health of the dam. Also to study its effect on ovarian activity of the dam and the number and weight of their litters.

\section{MATERIALS and METHODS}


Animals: Eighteen New Zealand white mature doe rabbits, weighting 2.7-3 kg were used. Animals were isolated for one week before the experimental procedure. They were in isolated batteries under hygienic conditions, fed on balanced ration and watered ad libitum.

Experimental protocol: Animals were divided into two equal groups $(n=9)$. The first group was fed on a basal diet and kept as control while the second group (treated group) was fed on the basal diet with addition of copper methionine. (Bioplexzn, Alltech). The suggested dose was 3 $\mathrm{mg} / \mathrm{kg}$ according to (Hunt and Carlton, 1965). It was given two months before matting and until three weeks post breeding (Muehlenbein et al., 2001). Does with ripen follicles can be recognized by inspection of the vulva which is dark red to purple. All does were matted at that time and immediately re-matted by the same buck to ensure adequate service (Cheeke et al., 1987). Ten days after matting does were palpated for pregnancy. Animals that failed to conceive were returned to a different buck in the same day and every day thereafter until they became pregnant. After parturition the does were divided into two subgroups to study the effect of supplementation on the ovary. Subgroup one slaughtered ten days after parturition, as in the semi-intensive rhythm (which is the most usual system) the does matted 10-12 days post partum in that system. Subgroup two was slaughtered after 21 days of parturition to study the effect of copper supplementation on the formation of the new wave of follicle in the ovary (Cheeke et al., 1987). The number of litters and their weight were recorded immediately after parturition. The mortality rate was recorded 21 days after parturition.

Blood sampling: Blood samples were taken from the ear vein 8 weeks after supplementation (first sample), 10 weeks after supplementation (second sample) during pregnancy (third sample), ten days after parturition (fourth sample); 21 days after parturition (fifth sample). After that serum was separated from whole blood by centrifugation and kept frozen for analysis of copper concentration, total antioxidants, nitric oxide, and lysozyme. Serum copper concentration was determined using atomic absorption spectrophotometer (Model-3300, Perkin Elmer, USA), total serum antioxidant was determined spectrophotometrically using standard diagnostic kit according to Koracevic et al. (2001). Nitric oxide was assayed according to Rajaraman et al. (1998). Lysozyme concentration in serum samples was determined according to Peeters and Vantrappen (1977). 
Histological samples: Ovaries were dissected immediately after slaughtering and cleared from excess tissues. The total number of corpora lutea were counted grossly and compared with the number of born litters. Then, the ovaries were fixed in Bouin's and processed by the usual histological techniques to obtain paraffin section of $5-6 \mu \mathrm{m}$ thickness. Each ovary were cut serial sections, one section was taken every 5 sections (they were acted as a representative sample of the ovarian status). These sections were stained with Hematoxylin and Eosin (Drury and Wallungton, 1980). The average number of dominant follicles, ovulatory and non-ovulatory, was counted in this section in both control and treated groups.

Statistical analysis:

Data were analyzed using SAS/STAT (1989).

\section{RESULTS}

As shown in Figure (1) serum copper concentrations were generally high in does fed $3 \mathrm{mg} / \mathrm{kg}$ chelated copper methionine compared to control. There was significant increase $(\mathrm{P}<0.01)$ in serum copper concentration in the first, second, and fifth samples while the third and fourth samples were not significantly affected.

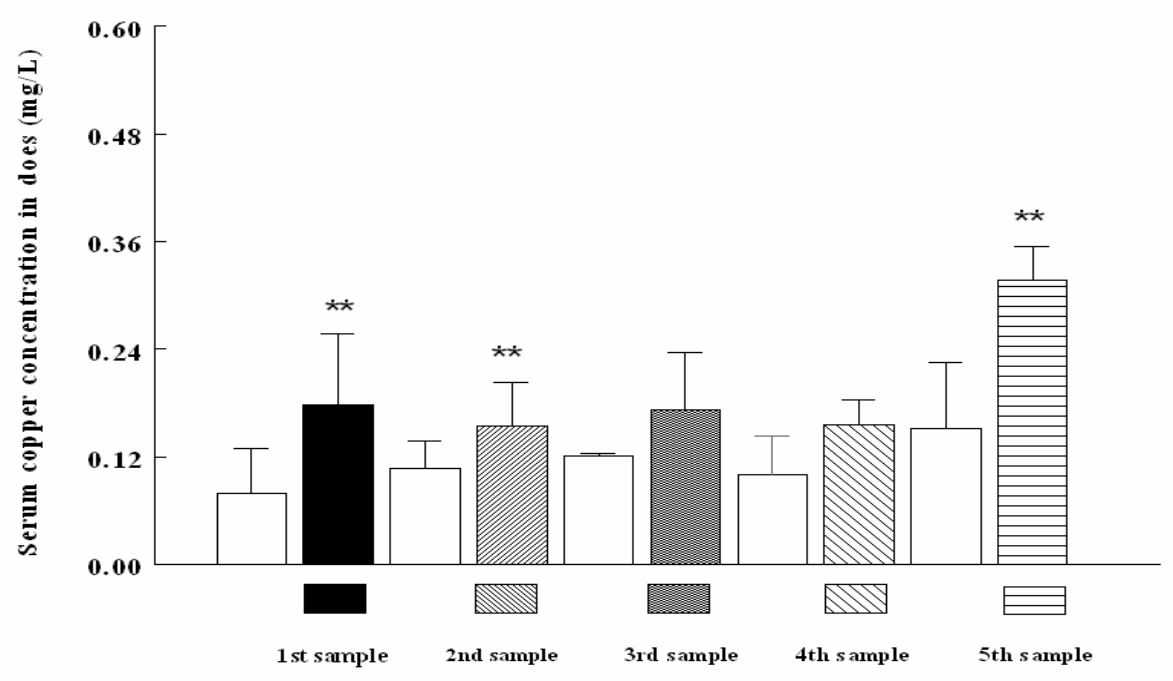

Fig. 1: Effect of copper methionine supplementation on serum copper concentrations $(\mathrm{mg} / \mathrm{L})$ in does. ** Significantly different from control at $\mathrm{P}<0.01$. 


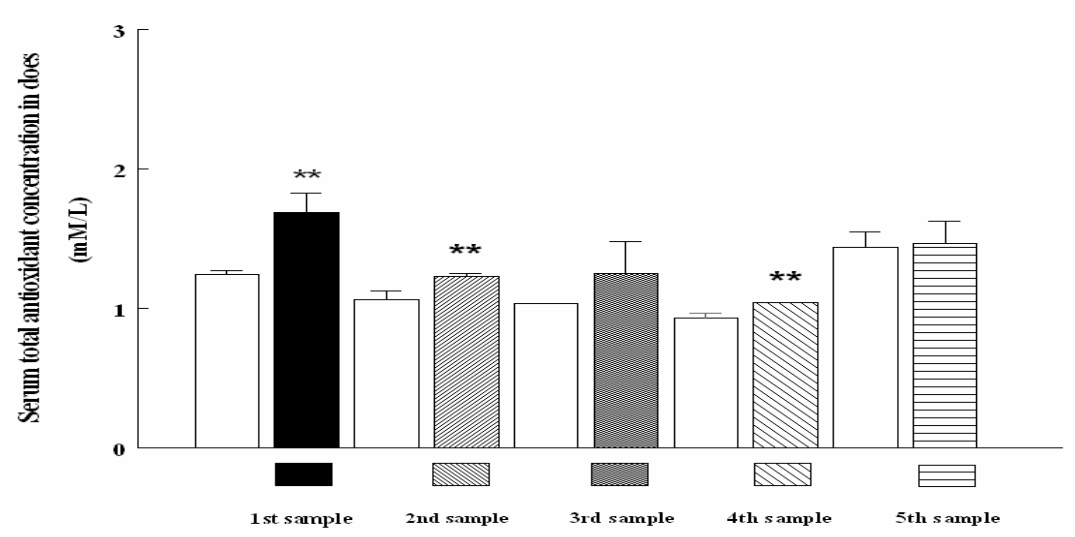

Fig. 2: Effect of copper methionine supplementation on serum total antioxidant concentrations in does. $* *$ Significantly different from control at $\mathrm{P}<0.01$.

The estimation of serum concentration of total antioxidant in does was represented in Figure 2. The serum concentration was significantly $(\mathrm{P}<0.01)$ increased in the first, second and fourth sample while the third and fifth samples were not significantly affected compared with the control.

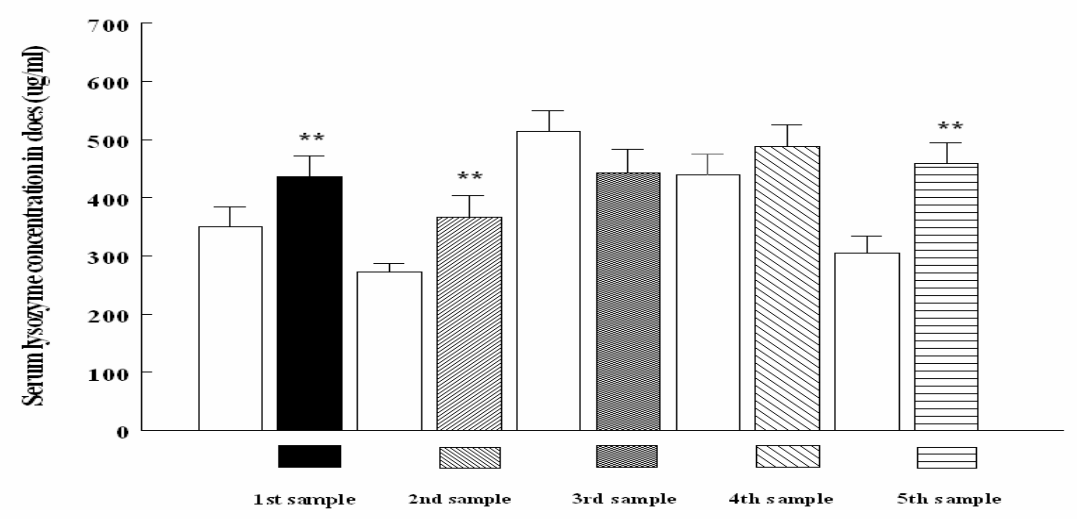

Fig. 3: Effect of copper methionine supplementation on serum copper concentration in does. $* *$ Significantly different from control at $\mathrm{P}<0.01$.

Serum concentration of lysozyme in does was represented in Figure 3. Serum concentration was significantly increased in the first, second, and fifth samples while the third and fourth samples were insignificantly affected compared with control. 


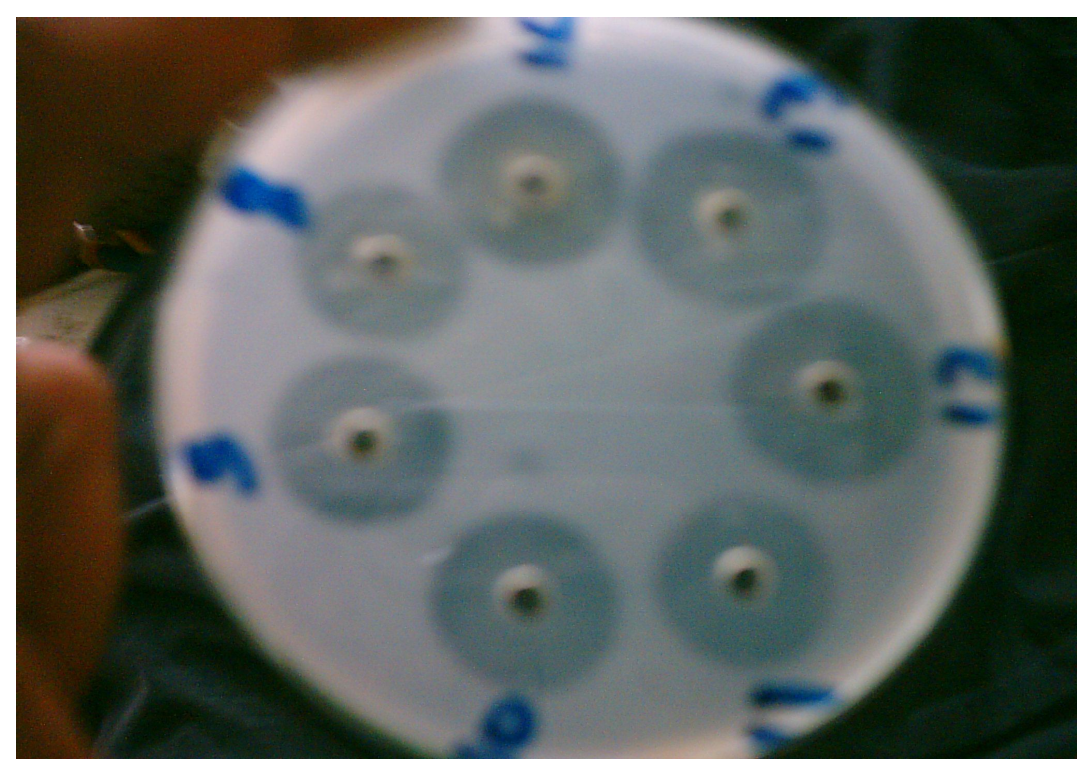

Fig. 4: Photo picture of the lysoplate showing the clearance zone caused by lysozyme in sera of does in the agarose plate.

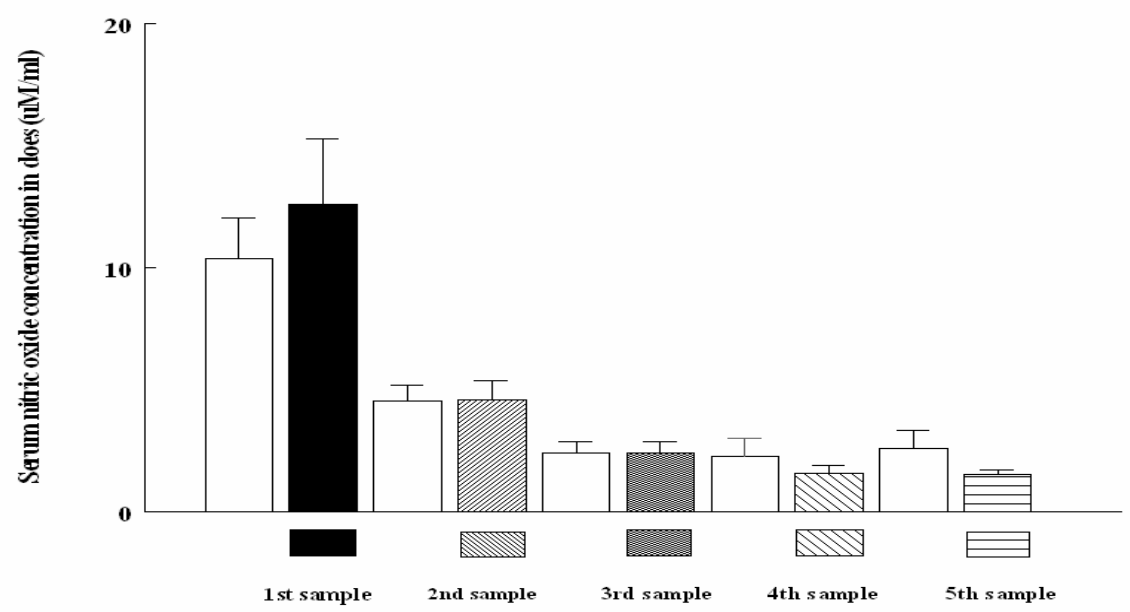

Fig. 5: Effect of copper methionine supplementation on serum nitric oxide concentration in does. ** Significantly different from control at $\mathrm{P}<0.01$.

Serum concentrations of nitric oxide did not significantly change between the control and treated does in the five samples. On the other hand nitric oxide concentration was decreased gradually during the whole experiment between the treated samples. 
Table 1: Effect of copper methionine supplementation on the ovarian structures in does slaughtered 10 days post partum.

\begin{tabular}{|l|c|c|}
\hline \multicolumn{1}{|c|}{ Item Control } & Treated \\
\hline $\begin{array}{l}\text { Average number of dominant } \\
\text { follicles (ovulatory and non- } \\
\text { ovulatory) }\end{array}$ & $2.0416 \pm 0.204$ & $1.77 \pm 0.137$ \\
\hline $\begin{array}{l}\text { The percentage of births /number } \\
\text { of corpora lutea }\end{array}$ & $50 \%$ & $94.11 \% * *$ \\
\hline
\end{tabular}

** Significantly different from control at $\mathrm{P}<0.01$.

In the present study, the ovarian sections of does slaughtered 10 days post partum act as a pool of lutin cells in which corpus luteum of pregnancy and small number of follicles (ovulatory and nonovulatory) are distributed. The ovarian sections of copper methionine treated does revealed non significant difference in the number of dominant follicles (ovulatory and non-ovulatory) compared to control (Figure 6). However, there was a significant increase $(\mathrm{P}<0.01)$ in the percentage of births to the number of corpora lutea in the treated group compared to control group (Table 1).

Table 2: Effect of copper methionine supplementation on the average number of ovarian follicles in does slaughtered 21 days post partum.

\begin{tabular}{|l|c|c|}
\hline \multicolumn{1}{|c|}{ Item Control } & Treated \\
\hline $\begin{array}{l}\text { Average number of dominant } \\
\text { ovulatory follicles }\end{array}$ & $1.741 \pm 0.19$ & $3.45 \pm 0.295^{* *}$ \\
\hline $\begin{array}{l}\text { Average number of dominant non- } \\
\text { ovulatory follicles }\end{array}$ & $1.33 \pm 0.1193$ & $2.43 \pm 0.258^{* *}$ \\
\hline $\begin{array}{l}\text { Average number of dominant } \\
\text { ovulatory and non-ovulatory } \\
\text { follicles }\end{array}$ & $2.526 \pm 0.240$ & $5.7 \pm 0.389^{* *}$ \\
\hline
\end{tabular}

** Significantly different from control at $\mathrm{P}<0.01$.

The ovarian sections of does slaughtered 21 days post partum showed regressed C.L and a large number of follicles (ovulated and nonovulated). The ovarian sections of copper methionine treated does revealed significant increase in the average number of dominant ovulatory and non-ovulatory follicles compared to control (Table 2) (Figures 7 and 8). 
Table 3: Effect of copper methionine supplementation in does on litters.

\begin{tabular}{|l|c|c|}
\hline \multicolumn{1}{|c|}{ Item } & Control & Treated \\
\hline Average number of born litters & $5.625 \pm 0.595$ & $5.714 \pm 0.521$ \\
\hline $\begin{array}{l}\text { Average weight of litters at } \\
\text { birth }\end{array}$ & $44.034 \pm 2.169$ & $57.44 \pm 4.666^{* *}$ \\
\hline $\begin{array}{l}\text { Percent of mortality rate } 21 \\
\text { days post partum }\end{array}$ & $61.9 \%$ & $40.9 \% * *$ \\
\hline
\end{tabular}

** Significantly different from control at $\mathrm{P}<0.01$.

The number of born litters was significantly unaffected by copper methionine supplementation compared to control (Table 3) whereas weight of litters at birth was significantly increased in the treated group compared to the control. The percent of mortality rate at 21 days post partum was significantly lower in the treated group compared to the control group.

Fig. 6: Cut section of the ovary of dose at 10 days post partum. Notice the presence of 3 dominant follicles and 5 corpus luteum Stain: H\&E X:7.3 
Fig. 7: Cut section of the ovary of normal does at 21 days post partum. Notice the presence of 1 dominant ovulatory and 3 non ovulatory Stain: H\&E X: 9.2

Fig. 8: Cut section of the ovary of copper methionine treated dose at 21 days post partum. Notice the presence of 2 dominant ovulatory and 12 non ovulatory Stain: H\&E X:9.2 


\section{DISCUSSION}

The increased copper concentration in the serum of does fed chelated copper methionine in this experiment supports previous works (Wittenperg et al., 1990, Kegley and Spears 1994 and Olson et al., 1999) who reported that both organic and inorganic copper increased concentrations of copper in bovine plasma. The serum copper concentration in the third and fourth groups tended to be increased but not significantly compared with the control. The reason for this difference is not clear but may be due to the physiological status of the animal and the effect of pregnancy (in the third sample) and the early lactation (in the fourth sample) of does. Gooneratne and Christensen, 1985 found a progressive increase in copper deposition in the fetal liver associated with a decrease in maternal liver copper during the last trimester of pregnancy Also Muehlenbein et al. (2001) observed that the cow at ten days post calving had liver copper concentration $23 \mathrm{mg} / \mathrm{kg}$ considered deficient and they produced calf 10 day of age with a liver copper concentration of $106 \mathrm{mg} / \mathrm{kg}$. The used dose of copper in this experiment might be responsible. (Cavalcanete et al., 2002) used higher doses in rabbits $(20,40,80 \mathrm{mg} / \mathrm{kg})$ for bioavailability of copper from different sources study.

The copper containing protein in most aerobic cells possesses super oxide dismutase activity (Nicholas, 1988) which is an essential component of the total antioxidant system. Total antioxidant concentration in the serum of does under experiment was generally increased in the treated group compared with control one. Suttle et al. (1987) noted that copper supplements to lambs markedly increased super oxide dismutase activity in erythrocytes. However, no treatment difference $(\mathrm{P}<0.01)$ was found in the third and fifth samples. These results indicate that copper supplementation to the doe did not increase serum total antioxidant concentrations during pregnancy and 21 days after parturition (peak of lactation) compared to control group. This effect may be due to excess production of reactive oxygen metabolites produced from the anabolic and catabolic processes occurred in both critical periods (Miller and Brzezinska, 1993).

Lysozyme is an enzyme secreted by the immune cells to defend against microbial infection by causing lyses of the microbial cell wall (Persson et al., 1992). Moreover, Olkowski, et al. (1990) reported an increase in the phagocytic activity of polymorphonuclear leukocytes in sheep fed on high copper diets. In current study chelated copper 
methionine supplementation to does significantly increased the concentrations of lysozyme in their sera especially in the first, second and fifth samples. In fact, the concentrations of copper in sera of does in some groups were also significantly high. It seems that copper as an antioxidant induced the immune cells to secrete more lysozyme which is a metabolite produced from the immune cells away from the oxidative pathway of nitric oxide and other reactive oxygen metabolites produced from the same immune cells. In 1971 (Saxena) reported that glutathione and copper had rapid regeneration effect on lysozyme.

Nitric oxide is a small molecule produced by many kinds of cells in the body such as phagocytic immune cells and having potent antimicrobial activity (Piddington et al., 2001). This activity is related to its action on many enzymes in the cells such as guanylyl catalase and reductase enzyme essential for DNA synthesis. Nitric oxide in nanomolar concentrations can effectively act as a regulator of the mitochondrial respiratory chain by binding to ferrocytochrome a3, competing with oxygen for this binding site. Nitric oxide also inhibits and inactivates glutathione peroxidase and superoxide dismutase enzymes that are important antioxidant enzymes (Asahi et al., 1995). Copper supplementation diminished the deleterious effects of oxidative metabolites on the cells (Mason et al., 2006). In Our study, treatment of does with chelated copper methionine decreased the concentrations of nitric oxide in their sera. Indeed, although the decrease was not significant, but yet it was gradual (over the treatment period) and consistent (Figure 5).

In post partum does follicular development generally occurs in waves; follicles reach mature size and actively produce estrogens for about 12-14 days but there is no ovulation till coitus occurs. If ovulation has not occurred the follicles degenerate with a corresponding reduction in sexual receptivity for 4 days, then a new wave of follicles will begin with a cycle of (16-18 days) (Cheeke et al., 1987) In our study the average numbers of dominant follicles (ovulatory and non-ovulatory) non-significantly differ in the does slaughtered ten days post partum and significantly increased in number 21 days post partum compared to control. Indeed, serum copper concentrations at the same two periods showed the same pattern, which means a direct effect of copper on the ovarian activity. The same observation noted by Stevenson and Jackson, (1980 and 1981) who studied the direct and indirect effects of added dietary copper sulphate in laying domestic fowl and concluded that there was evidence of a direct effect of copper sulphate on egg 
production and possible on oviduct and ovary weight. Also, Kendall et al. (2003) confirmed the same observation by studying the expression of mRNA for the copper-dependent enzyme, lysyl oxidase, and the effect of copper and/or copper chelating thiomolybdates on FSH-induced differentiation of bovine granulosa cells cultured in serum-free media. He concluded that thiomolybdates can prevent FSH differentiation of granulosa cells in vitro and these effects can be reversed by copper supplementation.

The percentage of births/the number of CL is significantly $(\mathrm{P}<0.01)$ increased in the treated group compared with the control one. This means that copper supplementation may reduce the early embryonic deaths or increase the fertilizing capacity of ovulated follicles. Graham (1991) and Takinguchi et al. (2000) suggested that zinc/copper superoxide dismutase play an important role in the regulation of corpus luteum function and maintaining steroidogeneses necessary to support pregnancy.

In the present study feeding does with $3 \mathrm{mg}$ chelated copper methionine did not significantly affect the number of young born but significantly increased the average weight of the individual young at birth. In this respect Schardein (1980) recorded that the feti are highly sensitive to drugs than adults. Krop (1990 and 1993) observed that beef cows supplemented with chelated minerals have heavier calves at weaning than did controls. However, Muehlenbein et al. (2001) concluded that copper supplementation to the dams both before and after calving did not improve calf health or growth.

The newly born litters are totally dependent upon their mother's milk for the first ten days of life. They begin eating solid food at three weeks of age. In our study the mortality rate in the first 21 days post partum is significantly lower in treated group compared to control one. The present result may be due to the improvement of the health status of litters by copper supplementation to their dam which may affect the mineral status of the litters or may improve both quality and quantity of milk. (Foley and Otterby, 1978; Ahola et al., 2004).

\section{CONCLUSION}

In general, chelated copper methionine supplementation to the dam at $3 \mathrm{mg} / \mathrm{kg}$, 2months, before mating and until 3 weeks postbreeding, did not affect serum copper total antioxidant and lysozyme concentrations during pregnancy and lactation periods. There were 
improvements in the percentage of birth/number of corpus luteum at 10 days after parturition and the ovarian activity at 21 days after parturition. There was significant increase in the weight of litters at birth and significant decrease in the percentage of litter mortality 21 days post parturition.

\section{REFERENCES}

Ahola, J.M.; Baker, D.S.; Burns, P.D.; Mortimer, R.G.; Enns, R.M.; Whitter, J.C.; Geary, T.W. and Englet, E. (2004): Effect of copper, zinc, and manganese supplementation and source on reproduction, mineral status, and performance in grazing beef cattle over a two-year period. J. Anim. Sci., 82(8): 2375-2383.

Asahi, M.; Fujii, J.; Suzuki, K.; Seo, H.G.; Kuzuya, T.; Hori, M.; Tada, M.; Fujii, S. and Taniguchi, N. (1995): Inactivation of glutathione peroxidase by nitric oxide. Implication for cytotoxicity. J. Biol Chem. Sep 8; 270 (36): 21035-9.

Campbell, M.H.; Miller, J.K. and Schrick, F.N. (1999): Effect of additional cobalt, copper, manganese, and zinc on reproduction and milk yield of lactating dairy cows receiving bovine somatotropin. J. Dairy Sci. 82: 1019-1025.

Cavalcante, S.G.; Ferreira, W.M.; Valente, S.S.; Santiago, G.S.; Dias, J.C. and Naranjo, A.P. (2002): Bioavailability of copper from different sources in rabbits. Arquivo-Brasilerio-de-MedicinaVeterinaria-e-Zootecnia. 53: 3, 290-294.

Cheeke, P.P.; Patton, N.W.; Lukefahr, S.D. and Mcnitt, J.I. (1987): Rabbit Production. $6^{\text {th }}$ Ed. Interstate Printers and Publ. Danville, Illinois.

Drury, R. and Wallington, E. (1980): Critons Histological Technique. 5th Ed., Oxford Univ Press, New York, Totonto.

Foley, J.A. and Otterby, D.E. (1978): Availability, storage, treatment, composition, and feeding value of surplus colostrum: A review. J. Dairy Sci. 61:1033-1060.

Goonerate, R. and Christensen, D. (1985): Gestation age and maternalfetal liver copper levels in the bovine. In Trace Elements in Man and Animals. Proc. 5th Int. Symp. On Trace Elements in Man and Animals. Farnham Royal Slough. UK. Pp 334-336.

Graham, T.W. (1991): Trace element deficiency in cattle. Vet. Clin. North Am. Food Anim. Pract. 7: 153-204. 
Hunt, C.E. and Carlton, W.W. (1965): Cardiovascular lesions associated with experimental copper deficiency in the rabbit. J. Nutr., 87: 385-393.

Kegley, E.B. and Spears, J.W. (1994): Bioavailability of feed-grade copper sources (oxide, sulphate, or lysine) in growing cattle. J. Anim. Sci., 72: 2728-2734

Kendall, N.R.; Marsters, P.; Scaramuzzi, R.J. and Kampbel, B.K. (2003): Expression of lysyl oxidase and effect of copper chloride and ammonium tetrathiomolybdate on bovine ovarian follicle granulose cells cultured in serum-free media. Reproduction, 125(5) 657-665.

Kincaid, R.L.; Blauwiekel, R.M. and Cronrath, J.D. (1986): Supplementation of copper as copper sulphate of copper proteinate for growing calves fed forages containing molybedenum. J. Dairy Sci. 69: 160-163.

Koracevic (2001): Colorimetric method for determination of total antioxidant capacity. J. Clin. Pathol. 54: 356-361.

Krop, J.R. (1993): The role of copper in beef cattle fertility. Pages 154169 in The Roles of Amino Acid Chelates in Animal Nutrition. H.D. Ashmead, ed. Noyes Pupl., Park Ridge. NJ.

Krop, J.R. (1990): Reproductive performance of first-calf heifers supplemented with amino acid chelate minerals. In: Oklahoma Anim. Sci. Res. Rep. 41 pp 35-43. Oklahoma State Univ., Stillwater.

Mason, M.G.; Nicholls, P.; Wilson, M.T. and Cooper, C.E. (2006): Nitric oxide inhibition of respiration involves both competitive (heme) and noncompetitive (copper) binding to cytochrome c oxidase. Proc Natl Acad Sci U S A. 2006 Jan 17; 103 (3): 708-13.

Miller, T.K. and Brzezinska, A. (1993): Oxidative stress, antioxidants and animal function. Journal of Dairy Sci., 76(9) 2812-2823.

Muehlenbein, E.L.; Brink, D.R.; Deutscher, G.H.; Cerlson, M.P. and Johnson, A.B. (2001): Effects of inorganic and organic copper supplemented to first-calf cows on cow reproduction and calf health and performance. J. Anim. Sci., 79: 1650-1659.

Nicholas, B.L. (1988): Veterinary pharmacology and therapeutics. 6th Ed. Iowa State University Press.

Nockels, C.F.; Debonies, J. and Torrent, J. (1993): Stress induction affects copper and zinc balance in calves fed organic and inorganic copper and zinc sources. J. Anim. Sci. 71:2539-2545. 
Olkowski, A.A.; Gooneratne, S.R. and Christensen, D.A. (1990): Effects of diets of high sulphur contents and varied concentrations of copper, molybedenum and thiamine on in vitro phagocytic and candidacial activity of neutrophils ion sheep. Res. Vet. Sci. 48: 82-86.

Olson, P.A.; Brink, D.R.; Hickok, D.T.; Carlson, M.P.; Schneider, N.R.; Deutscher, G.H.; Adams, D.C.; Colburn, D.J. and Johnson, A.B. (1999): Effects of supplementation of organic and inorganic combinations of copper, cobalt, manganese, and zinc above nutrient requirement levels on postpartum two-year-old cows. J. Anim. Sci., 77(3) 522-532.

Peerters, T.L. and Vantrapen, G.R. (1977): Factors influencing lysozyme determinations by lysoplate method. Cli. Chim. Acta 74: 217-255.

Persson, K.; Carlsson, A.; Hambleton, C. and Guidry, A.J. (1992): Immunoglobulins, lysozyme and lactoferrin in the teat and udder of the dry cow during endotoxin-induced inflammation. Zentralbl Veterinarmed B., 39(3): 165-74.

Piddington, D.L.; Fang, F.C.; Laessig, T.; Cooper, A.M.; Orme, I.M. and Buchmeier, N.A. (2001) $\mathrm{Cu}, \mathrm{Zn}$ superoxide dismutase of Mycobacterium tuberculosis contributes to survival in activated macrophages that are generating an oxidative burst. Infect Immun. 69(8): 4980-7.

Rajaraman, V.; Nonnecke, B.J.; Franklin, S.T.; Hammell, D.C. and Horst, R.L. (1998): Effect of vitamins A and $\mathrm{E}$ on nitric oxide production by blood mononuclear leukocytes from neonatal calves fed milk replacer. J Dairy Sci., 81: 3278-3285.

SAS/STAT User's Guide (1989): Statistic, Version 6, $4^{\text {th }}$ Ed. SAS Inst., Inc., Cary, NC.

Saxena, V.P. and Wetlaufer, D.B. (1971): Biochemistry 9, 5015.

Schardien, J.L. (1980): Drugs As Teratogens. CRS Press, Inc. Ohio, pp 169-192.

Stevenson, M.H. and Jackson, N. (1981): An attempt to distinguish between the direct and indirect effects, in the laying domestic fowl, of added dietary copper sulphate. Br J. Nutr.; 46(1): 71-6.

Stevenson, M.H. and Jackson, N. (1980): Effects of withdrawal of copper sulphate from the diet of the mature domestic fowl with special reference to production and tissue mineral content. Br J. Nutr.; 43(3): 551-9. 
Suttle, N.F.; Jones, D.G.; Woolliams, C. and Wooliams, J.A. (1987): Heinz body anemia in lambs with deficiency of copper or selenium. Br. J. Nutr., 58(3) 539-548.

Swenson, C.K.; Anstoegui, R.B.; Swenson, E.J.; Paterson, J.A. and Johnson, A.B. (1998): Trace mineral supplementation effects on first-calf beef heifer reproduction, milk production and calf performance. Proc. West. Sec. Amer. Soc. Anim. Sci. 49: 327-331.

Takinguchi, S.; Sugino, N.; Kashida, S.; Yamagata, Nakamuray and Katott (2000): Rescue of the corpus luteum and an increase in luteal superoxide dismutase expression induced by placental luteotropins in the rat: action of testosterone without conversion. Biol. Reprod., 62, 398-403.

Thomas, B.B. (1994): Veterinary Drug Therapy. Lea and Febiger Philadelphia. USA.

Underwood, E.J. and Suttle, N.F. (1999): The mineral Nutrition of Live Stock. 3rd Ed. CABI publishing Co., New York.

Vanegas, J.A.; Reynolds, J. and Atwill, E.R. (2004): Effects of an injectable trace mineral supplement on first-service conception rate of dairy cows. J. Dairy. Sci. 87: 3665-3671.

Wittenberg, K.M.; Boila, R.J. and Shariff, M.A. (1990): Comparison of copper sulfate and copper proteinate as copper source for copper-depleted steers fed high molybedenum diets. Can. J. Anim. Sci. 70: 895-904. 